\title{
Iran and Its Boundaries in Challenging with Foreign Relation (1789 - 1836)
}

\author{
Jafar Aghazadeh $^{1}$, Morteza Dehgan Nezhad ${ }^{1} \&$ Asgr Mahmud Abade ${ }^{1}$ \\ ${ }^{1}$ Department of History, University of Isfahan, Isfahan, Iran \\ Correspondence: Jafar Aghazadeh, Department of History, University of Isfahan, Isfahan, Iran. Tel: \\ 98-914-960-9010. E-mail: j.agazadeh@yahoo.com
}

Received: January 25, 2012

Accepted: March 11, $2012 \quad$ Published: July 1, 2012

doi:10.5539/ach.v4n2p159

URL: http://dx.doi.org/10.5539/ach.v4n2p159

\begin{abstract}
From ancient times, Iran's boundaries were formed by Iranian kings' struggles. From that time, an imagination about these boundaries was formed in Iranian minds and has been continued until now. So, one of the important duties of Iranian kings was to expand Iran's boundaries to that of ancient times. The aim of this research is to investigate Iran's relations with European countries and the role of these relations in forming the Iran's boundaries from 1789 to 1828 . In this research, a descriptive-analytic method is used. The findings of this research show that in Qajar dynasty, Agha Muhammad Khan and Fath Ali shah made some great attempts to expand Iran's boundaries to that of ancient times in order to, through which, can legitimate their rule on Iran. These actions made Iran to enter European countries' politics widely. Russia advanced in Caucasus and the Britain entered Iran's affairs widely to protect its realms in India, and France set a relationship with Iran in order to access India. Entrance of the unknowledgeable Iranians in international politics led to Iranian amazement, and European countries' interference in forming the Iran's boundaries, and, step by step, Iran lost some of its parts.
\end{abstract}

Keywords: Iran, Agha Muhammad Khan, Fath Ali shah, Iran's boundaries, international politics

\section{Introduction}

During their long history, Iranians have had a lucid imagination from Iran's boundaries, and always expected from their kings to expand Iran's boundaries to its real limitations; therefore, that was one of the most important duties of Iranian kings in Iranian minds, and was one of the factors of Iranian king's success and their popularity among people. In Iran's Islamic era, the Safavid dynasty could expand Iran's boundaries to its ancient limitations. Then, Agha Muhammad Khan made great attempts to, restoration Iran's boundaries and, to do so; he had to encounter with Russians but his early death prevented him from a severe challenge with them. His Successor, Fath Ali Shah paid much attention to expand Iran's boundaries to Khurasan and Caucasus, and his attempts made him to fight with Russians, but, because of being less powerful than them, he had to ask for help from France and, then, the Britain. Iran's geographical position on the borders of Russia, India and the Persian Gulf turned her into a natural target in the political struggle between France and Britain early in the $19^{\text {th }}$ century and that between Russia and Britain throughout the $19^{\text {th }}$ and early $20^{\text {th }}$ centuries. Political and strategic interests were of primary concern to both Britain and Russia. Britain was mainly covered with preserving the formal independence and integrity of Iran in order to defend the Indian empire. This required her to retain control of the Persian Gulf, to keep all other powers out of it, and to safeguard southern and eastern Iran. Russia deprived Iran of her Transcaucasia territories in the first half of $19^{\text {th }}$ century. Both Britain and Russia were striving to exercise as much influence as possible on the Qajar rulers in order to gain support for their actions in Iran and to repel their rivals. Qajar's unawareness to International politics in these relations and their trust to Europeans, Iranians bore lots of loses. Europeans' interference in Iran's affairs and their avarice led to separation of some parts of Iran. Until now, no serious research has been done about Qajar's attempts for restoration of Iran's boundaries and the role of European countries in separation of Iran's parts in early years of Qajar dynasty; therefore, the lack of research in this area was the incentive of this study. Using a descriptive- analytic method, this research is to investigate Iran's relations with European countries and their interference in forming Iran's boundaries in early years of Qajar dynasty. 


\section{Agha Muhammad Khan and Iran Boundaries}

Iran had a long tradition and background as a great empire ruled by a King of Kings and the important task of the early Qajar kings, having restored internal security, was to recover the border areas and restore the empire to the preceding Safavid limits. Aga Muhammad Khan ( ruled 1789- 1797), founder of the Qajar dynasty, had begun by invading Georgia and Khurasan and Iran borders, continued to be directed towards these two areas. With this, he sought to legitimize his rule as the Iranian King.

To achieve this goal, in the spring of 1795 , he assembled a force and went to Azerbaijan, intending to conquer the country between the rivers Aras and Kura, formerly under Safavid control. This region comprised a number of independent khanates, much had happened in Georgia since the fall of the Safavids. Russian and Iranian relations were interconnected with their politics in the Caucasus in the late of $18^{\text {th }}$ century and in the first half of $19^{\text {th }}$. Russia's main ally in the Caucasus was Christian Georgia, which was seeking Russia's protection from the Muslim Iranians and Ottomans. Catherine II viewed Georgia as an essential part of her Asian politics because in provided a vital strategic base for operations against Iran and Ottoman Empire. Recently, on 24 July 1783, Erekle (Heraclius), the ruler of Kartli and Kakheti (the central core of the Georgian kingdom) and Catherine II of Russia had signed the Treaty of Georgievsk which made Georgia a Russian protectorate. In it, Erekle specifically renounced Georgia's former dependence upon Iran, while another article of the Treaty allowed the stationing of Russian troops in Georgia for mutual defense against Iran and Ottomans (Avery, Hambly, \& Melville, 2008).

Agha Muhammad Khan cannot have been ignorant of events in Georgia, or unaware of Russia's threatening presence beyond the Caucasus. His suspicions had been aroused by recent Russian activity in both Gilan and Astarabad. This may explain part of the hostility he felt towards the ruler of Georgia, although while the Zands were still undefeated he had remained ostensibly amicable. In 1786, soon after the death of Ali Murad Khan Zand, he received an envoy from Erekle, and offered the latter sovereignty over Azerbaijan, not then in his possession, if Erekle could obtain Russian backing for him in his conflict with the Zands. Five years later, his conquest of Azerbaijan in 1791 raised apprehensions in Tiflis, and Erekle had applied to Saint Petersburg for assistance, in accordance with the terms of the Treaty of Georgievsk, although without result, since the Russian government was preoccupied elsewhere. As soon as Erekle heard of Agha Muhammad Khan's plans for a summer campaign across the Aras in 1795, he sent an urgent request to Saint Petersburg for Russian aid. None was given, however, largely on the advice of General Ivan Gudovich, the commander of the Caucasian line, who did not take the threat seriously (Rustam al-Hukama, 2001).

Meanwhile, Agha Muhammad Khan had left Shusha and advanced on Ganja, where the ruler, Javad Khan, submitted. From there, he sent a threatening letter to Erekle. He reminded him that, under the Safavids, Georgia had been a part of Iran and demanded Erekle's immediate submission, assuring him that if he came to pay homage, he would be confirmed as Vali. Agha Muhammad Khan declared that "Shah Esmaeil Safavi ruled over the province of Georgia. When in the days of the deceased king we were engaged in conquering the provinces of Iran, we did not proceed to this region. As most of the provinces of Iran have come into our possession now, you must, according to ancient law, consider Georgia part of the empire and appear before our majesty. You have to confirm your obedience; then you may remain in the possession of your governorship. If you do not do this, you will be treated as the others" (fasai, 2004).

Erekle reject Agha Muhammd Khans request, so reaffirm his allegiance to Russia and summon all the troops he could muster to Tiflis. With this Agha Muhammad Khan came up to Tiflis 10 September 1795 and a decisive engagement took place outside Tiflis. The battle lasted a whole day (Malcolm, 1815: 284). Eventually the Georgians had suffered heavy casualties and had retreated into the citadel of Tiflis. Later, what remained of the Vali's army, and those inhabitants of Tiflis who could, abandoned the city. Tiflis was sacked, and after the devastation and massacre, 15,000 Georgian slaves, mostly women and children, were deported to Iran (Al- Saruii, 1992).

Agha Muhammad Khan remained nine days in the vicinity of Tiflis. His victory proclaimed the restoration of Iranian military power in a region formerly under Safavid domination. Georgia had been punished and Russia's prestige damaged. But Agha Muhammad Khan did not stay to consolidate his victory. He turned back and marched down the valley of the Kura and, having ravaged the Khanate of Shirvan, established his winter quarters in the Mughan steppe (Avery, Hambly, \& Melville, 2008).

Agha Muhammad Khan had hitherto refused the title of Shah, on the grounds that Iran was not entirely subject to his authority. Now, the Qajar chieftains and officers of state came and pressed him to take the title of Shah before marching on Mashhad and bringing the former Safavid province of Khurasan, as far as the Amu-Darya River, under his protection. In agreeing to their petition, Agha Muhammad Khan said, "If, according to your 
desire, I put the crown on my head, this will cause you, in the beginning, toil and hardship, as I take no pleasure in bearing the title of king as long as I am not one of the greatest kings of Iran. This petition will not be granted but by toil and fatigue"(fasai, 2004). Agha Muhammad Khan intended to make his coronation ceremony an act of legitimating. Following the Safavid custom, the sword of Shah Ismaeil Safavi was suspended from the roof of the tomb-chamber of Shaikh Safi at the shrine of Ardabil on the eve of the coronation, while prayers were offered for the new Shah's welfare (Malkolm, 1815).

Shortly afterwards, the Shah and his army was headed to Khurasan. This territory, untouched by the earlier struggles among the Zand and Qajar rivals, had formerly been protected by the Durrani ruler, Ahmad Shah, but after his death in 1773, his successors preferred to concentrate their attention upon their Indian borderlands. In the late decades of the $18^{\text {th }}$ century, Khurasan was in a state of near anarchy. In Mashhad, the authority of Shahrukh, Nadir Shah's grandson, was hardly more than nominal. Outside Mashhad, the surrounding countryside was held by various independent chieftains. Across this vast expanse, tribal warfare, the plundering of caravans and cattle and slave-raiding were endemic. The newly-crowned Agha Muhammad Shah advanced into Khurasan by way of Gurgan, halting in Astarabad to punish the Goklen Turkmens who had been raiding in that province (Fraser, 1825).

He then left for Mashhad, while local khans, recognizing the impossibility of resistance, hastened to submit. All these chieftains were forced to hand over hostages, who were sent to Tehran. As Agha Muhammad Shah approached Mashhad, Shahrukh came to the Qajar camp, accompanied by one of his sons. The next day, Agha Muhammad Shah entered Mashhad on foot (as Shah Abbas I had been accustomed to do) as a pilgrim to the shrine of Imam Riza, weeping and kissing the earth. For the next twenty-three days, he continued his pilgrimage, seemingly oblivious of affairs of state. Then a change came over him. Orders were given for the exhumation of Nadir Shah's remains, which were reburied with those of Karim Khan Zand in Tehran; Shahrukh was compelled to surrender any jewels formerly belonging to Nadir Shah (Hidayat, 2001). Shahrukh and his family were then sent to Mazandaran. Shahrukh himself died on the way, at Damghan. He was sixty-three, and had ruled Khurasan, in name at least, for forty-six years. The Shah had arrived in Mashhad in May 1796. He seems to have spent some time there, settling the affairs of Khurasan. It is possible that he contemplated advancing against Herat, then an appendage of the Durrani kingdom, but formerly a Safavid province and traditional residence of the Safavid Valiahd. He may also have contemplated an expedition against Bukhara, to avenge the Mangit usurper Shah Murad's treatment of the Qajars of Marv. He sent an emissary to Bukhara, addressed not to Shah Murad, but to Abul-Ghazi Khan, last ruler of the dispossessed Janid dynasty, demanding the return of Iranian slaves held in Bukhara. Shah Murad is said to have replied insultingly, but to have assembled the Iranian captives in Bukhara so that they should be ready, if necessary, to be returned to Iran. Agha Muhammad Shah is also supposed to have proposed at this time a combined attack on Bukhara to Timur Shah Durrani ( Hidayat, 2001).

In the event, news of developments in the north-west called for immediate action. Catherine II, eager to extend Russia's hegemony beyond the Caucasus, and having a pretext in the Shah's treatment of her client, Erekle, had sent an expedition into the south-eastern Caucasus, under the command of Count Valerian Zubov. Its goal was to annex the Kura-Aras region and penalize the Aga Muhammd. Zubov first occupied Darband and Baku, the districts of Salyan and Talish, and then Shamakhi and Ganja. In this rime, the death of Catherine in November 1796, and the accession of Paul I, opposed to his mother's Caucasian policies, led to the expedition's recall (Sipihr, 1998).

Meanwhile, the Shah had returned to Tehran, ordering the military commanders to assemble there with their contingents the following spring. Agha Muhammad Shah apparently contemplated an extended campaign to punish the Russians. In June 1797, the Shah left Tehran, intending to march through Azerbaijan to Qarabagh, Shirvan and Georgia, but in camp at Sultaniya, the news of Zubov's recall arrived. This led to a change of plan. It was less urgent to punish Georgia and Russia, and the Shah decided to deal first with the recalcitrant Ibrahim Khan of Qarabagh, who had recently become a Russian protege. The royal army therefore moved towards Shusha. At Adinabazar, there appeared a delegation of notables from Shusha, announcing that Ibrahim Khan and his family had fled into Daghistan, and inviting the Shah to take possession of their city. In response to this unanticipated good fortune, he entered Shusha. He remained there three days until, disturbed one evening by a quarrel between two servants in his private quarters, he ordered their immediate execution and then postpone their execution until the following morning, to avoid shedding blood on a Friday. He foolishly allowed the condemned men to continue attending him until he fell asleep, when they, joined by a third servant, stabbed him to death, on 16 June 1797. (Dunbuli, 2004 ) 
Agha Muhammad Khan's attempts for keeping sovereignty of Iran on Caucasus were faced with resistance of the local Khans and Russia. He was killed for the sake of restoration of Iran's ancient boundaries, but the Russians' avarice for surrounding this region and the attempts of their Khans for independence never stopped.

\section{Fath Ali Shah in Challenging with European's}

In 1789, Fath Ali Shah (ruled 1797-1834) crowned and could suppress his domestic rivals successfully (sipihr, 1998). The first moves of his were in the east. In 1799 he advanced to Mashhad but stopped there when he learned that the Afghan ruler, Zaman Shah, had marched to Herat. In 1802 the Iranians were in Mashhad again where they consolidated their hold and three years later they attacked Herat. Internal troubles in Afghanistan prevented aid from reaching the Afghan governor there, and after a Iranian victory at Ghurian, he ceded that border fortress to Iran and agreed to pay tribute for Heart (Elphinstone, 1815; Watson, 1866). Iranians was prevented from following up this success however, because war had broken out with Russia.

In 1801, Georgia was annexed to Russia. Emperor Alexander I (ruled 1801-1825) appointed Prince Tsitsianov as commander-in-chief in the Caucasus, whose directive was to impose Russian rule on the Caucasian territories adjacent to Georgia. Some Khanates submitted; others became victims of military conquest. After Prince Tsitsianov captured the city of Ganja and appeared before the city of Erevan, the first Russo-Iranian war broke out. The Iranian army was led by Abbas Mirza, heir of Fath Ali Shah and Governor of Azerbaijan (baddely, 1908).

This war lasted nine years, during which time Iran first became involved in European diplomacy. Napoleon's invasion of Egypt in 1798 and the Afghan Zaman Shah's repeated wars in the Punjab aroused British fears for their possessions in India (Dunbuli, 2004).

Iran was seen by Britain as a potential check on both these threats and a mission was sent to Iran from India in 1801. But when Zaman Shah was deposed and Britain made peace with Napoleon, these feelers were not followed through. Napoleon on the other hand saw a way to get at both Britain and Russia through Iran. In 1807 Fath Ali Shah signed a treaty with Napoleon and welcomed a French military mission. When Napoleon made peace with Russia later that year however, the French pulled out and British interest in Iran revived. Britain signed a treaty with Iran in 1812 and reaffirmed it in 1814 (Sykes, 1915). The chief contexts of this treaty were that:

1) Iran would prevent any European army that attempted to invade India by way of Iran or Central Asia.

2) The defensive articles $(3 \& 4)$ would apply only in cases where the outside power was the aggressor (the only difference between the 1812 and 1814 treaties, this article was added to give the British a loophole).

3) Britain would aid Iran with either troops from India or a yearly subsidy in the event Iran became involved in a war with any European power.

4) This aid would be given even if Britain was at peace with the European power.

5) Iran would attack Afghanistan if the latter was at war with Britain.

6) Britain would not interfere in any war between Iran and Afghanistan. (Sipihr, 1998; Aitchison, 1865)

But the treaties signed with France and Britain proved to be fruitless. The defeat of Napoleon allowed to Russia to concentrate more resources on Caucasian front: the Battle of Aslanduz marked the final defeat of Iran, and the Treaty of Gulistan was signed in 1813. By the terms of treaty Iran lost most of her possessions, including Ganjeh, Darband, Baku and Georgia, gave up her right to maintain a navy on the Caspian, which thereby became the Russian lake (Kazemzadeh, 1968). The provisions concerning the border lines were vague and soon led to a new conflict.

During the first Russo-Iranian war, when the Iran first began to attract the sustained attention of European imperialism and colonialism, Abbas Mirza with the help of his minister Qa'im Magam, began a protracted experiment with army modernization. Thus in the Iran, nizam-i jadid (new order) regiments sprang up, sometimes on the ruins of older military formations, sometimes alongside them. Fath Ali Shah and Abbas Mirza embarked on army reform in a desperate effort to strengthen their defensive capacity, and to resist growing European hegemony and direct or indirect control by imitating European methods of military organization and warfare. Iranian politics invited European officers, sometimes as individuals, sometimes as formal missions, to assist with building a modern army. With the help of these officers, Iranian rulers thus sought to appropriate the secrets of European power. These early attempts at military modernization were partly driven by shock at successive defeats by Russian powers and by the Russian conquests of Iranian territory in Caucasus and the consequent extension of infidel control over Muslim populations. Fath Ali Shah hoped to equip his dynasty with a coercive weapon capable of quelling domestic opposition and maintaining borders of Iran against the enemies. 
But his protracted struggles to build up forces capable of defending their realms from external attack so that in following says largely failed (Keddie, 1981).

Iran's activities in the east had been curtailed while fighting Russia. The occasion of a major revolt by tribal chiefs in Khurasan in 1811 was used by the Afghans to retake Ghurian and stop paying tribute for Herat. Other revolts followed the unsuccessful war with Russia and it was not until 1816 that another effort could be made to advance the eastern frontiers. In that year the governor of Mashhad advanced on Herat but this time the Afghans were able to send a substantial army from their capital of Kabul to the scene. There was a battle in which both sides claimed victory but the Iranians did not get Heart (Ferrier, 1858; Watson, 1866).

During the 1820's Fath Ali Shah was occupied with war along the Ottomans border, and more seriously, a second war with Russia. Two Russian missions to Iran, on led by General Ermolov in 1817, the other by Prince Menshikov in 1826 failed to ease the tensions between Iran and Russia. Iran was dissatisfied with the settlement of 1813 in the Caucasus and in 1826, after the initial outbreak of fighting; a massive Iranian invasion threw back the Russian forces. Russia recovered swiftly however, and in the following year, Iran with only a minority of well-drilled and modernized forces was soon defeated (Sipihr, 1998) the Treaty of Turkmanchai, signed in 1928 was destined to regulate Russo-Persian relations until 1917. In addition to lands yielded under the Treaty of Gulistan had now to cede to Russian the khanates of Erevan Nakhichevan. Iran also had to pay Russia the considerable indemnity of 20 million rubles. (Shirazi, 2002)

During the war, Iran had appealed to the Britain for aid under the terms of the 1814 treaty. Britain however, trying to reach an accommodation with Russia, chose to see Iran as the aggressor and refused to extend any aid (Kelly, 1968). The British then negotiated a release from their obligation to aid the Iranians in return for a sum of money that Iran desperately needed to pay the first installment of the Russian indemnity (Watson, 1866). Thus, the effort of Fath Ali shah and his son, Abbas Mirza to exploit the rivalries between the European powers in order to regain the lost dominions of Safavid failed.

Efforts to regain the Caucasus ended with crushing defeats at the hands of the Russians. Even in the east where there was less opposition, the Qajars could make little headway. But far from giving up, after 1828 the Qajars would try even harder to recover the east to make up for what was lost forever in the west.

\section{Conclusion}

Agha Muhammad Khan and Fath Ali Shah made some great attempts to expand Iran's boundaries to that of ancient and Safavid times. Agha Muhammad Khan was so successful in doing so and in his time, the Russia's influence could not prevent him from fulfilling this wish. His swift action in Caucasus led to Russia's inaction. But his early death did not allow him experience serious relations and struggles with Russia and other European countries. Fath Ali Shah's attempts for supremacy on Caucasus and encountering with Russians (who wanted to attach Caucasus to their country) began the fights between Iran and Russia. In this time, Iran had to play a role in international politics unwontedly. Continuing Britain dominance on India in counter with the avarice of Iran, France, Russia and Afghans, so the Britain was involved in Iran's politics actively. Fulfilling the Napoleon Bonaparte's wish for attacking to India via Iran, France sent a delegation to Iran. European countries' entrance to Iran's politics baffled the unaware Qajars to international relations, and its fruit was adapting an unclear policy toward these relations so that, unknowing their goals and purposes, they ask for help from France and the Britain. The result of these unequal relations was that, because of their interference and Russia's power and Qajar weakness, some parts of Iran were separated.

\section{References}

Aitchison, C. U. (1865). A Collection of Treaties, Engagements, and Sunnuds Relating to India and Neighboring Countries (9 ol. 2). Calcutta, India: Government Printing.

Al-Saruii, M. T. (1992). Tarlkh-i Muhammadi. Tehran, Iran: Amir Kabir.

Avery, P., Hambly, G., \& Melville, C. (eds) (2008). The Cambridge History of Iran (9 ol. 7). Cambridge: Cambridge University Press.

Baddeley, J. F. (1908). The Russian Conquest of the Caucasus. New York: Russell and Russell.

Dunbuli, A. R. M. (2004). Maasir-i Sultdniya. Tehran, Iran: Ruznameie Iran.

Elphinstone, M. (1815). Account of the Kingdom of Caubul and its Dependencies in Persia, Tartary, and India. London: Longman etc.

Fasai, H. M. H. (2004). Farsndma-yi Nasiri (9 ol. 1). Tehran, Iran: Amir Kabir. 
Ferrier, J. P. (1858). History of the Afghans. London: J. Murray.

Fraser, J. B. (1825). Narrative of a Journey into Khorasan, in the Years 1821 and 1822 (9 ol. 1). London: Richard Bentley.

Hidayat, R. Q. K. (2001). Rauzat al-Safa-yi Nasiri (9 ol. 9). Tehran, Iran: Amir Kabir.

Kazemzadeh, F. (1968). Russia and Great Britain in Persia 1864-1914: A Study in Imperialism. New Haven: Yale University press.

Keddie, N. (1981). Roots of revolution: an Interpretive History of Modern Iran. New Haven: Yale University press.

Kelly, J. B. (1968). Britain and the Persian Gulf 1795-1880. Oxford: Clarendon Press.

Malcolm, S. J. (1815). A History of Persia (9 ol. 2). London: John Murray.

Rustamal-Hukama, A. M. H. (1969). Rustam al-Tavarikh. Tehran, Iran: Amir Kabir.

Shirazi, M. F. K. (2002). Tarikh-e Zol-Qarnein. Tehran, Iran: Vezarate Farhang.

Sipihr. M. T. L. (1998). Nasikh al-Tavarlkh (9 ol. 1). Tehran, Iran: Asatir.

Sykes, S. P. (1915). A History of Persia (9 ol. 2). London: Macmillan.

Watson, R. G. (1866). A History of Persia from the Beginning of the Nineteenth Century to the Year 1858. London: Smith and Elder. 